\title{
People Watching People Watchers: The Law Enforcement Company' for watc hing over those who come to see and be seen on the 'Urban Beach'
}

\author{
Steve Mann1
}

\begin{abstract}
This article presents my own personal narrative, in the existemology of a new but mostly deserted 'urban beach' right at downtown Toronto's epicentre. The new public space called 'Dundas Square', designed as 'Times Square North', forms Toronto's new civic center, around an urban beach theme with waterplay fountains, that rise and fall continuously, to create a beautiful and restful atmosphere of pounding surf. The space is policed by Intelligarde-International, which describes itself as 'The Law Enforcement Company'. The use of private security guards in an allegedly public space creates some unique problems in accountability and reciprocity in visibility. Unlike the lifeguards of a traditional beach, who are themselves young, playful, and part of the swimming community, Intelligarde alienates itself from the community through an authoritarian desire to be free of accountability. Citizens who go to the 'urbeach' to see and be seen, can be thought of as 'people watching people'. But unlike lifeguards at a traditional beach, who often help novice swimmers be comfortable in the water, Intelligardes are 'people watching people watchers' from a distance. The problem of private security in public space is twofold: (1) a private 'law enforcement company' is not subject to the same checks and balances as public lifeguards; (2) the double entendre of the words 'private security' is fulfilled. Not only is law enforcement of life in the public square privatized, but also the security guards enjoy a privacy (i.e. lack of accountability) that their 'citizens' (the surveilled) do not. This article describes my attempts at using "Times Square North" for its intended purpose, and the resulting problems that point to a need for participatory equiveillance.
\end{abstract}

\section{Introduction: Playing in the fountains}

As an inventor, I have been creating new kinds of waterplay fountains, including immersive multimedia environments for typing out messages by successively blocking various jets of a fountain, or touching a splash page in which a waterfall is used as a back-projected touch screen (see, for example: Mann et al., 2003). Other variations of my inventions include musical instruments that are similar to wind instruments like the tin flute, but are instead water instruments that are played by blocking various jets to make sound. In this way, 'playing in the fountains' is a

\footnotetext{
${ }^{1}$ Electrical and Computing Engineering, University of Toronto, mailto:mann@eecg.toronto.edu website: http://www.wearcam.org
} 
play on words, meaning: (1) playful fun and frolic in the fountains; (2) to play a song, or to play music, as shown in the following figure:

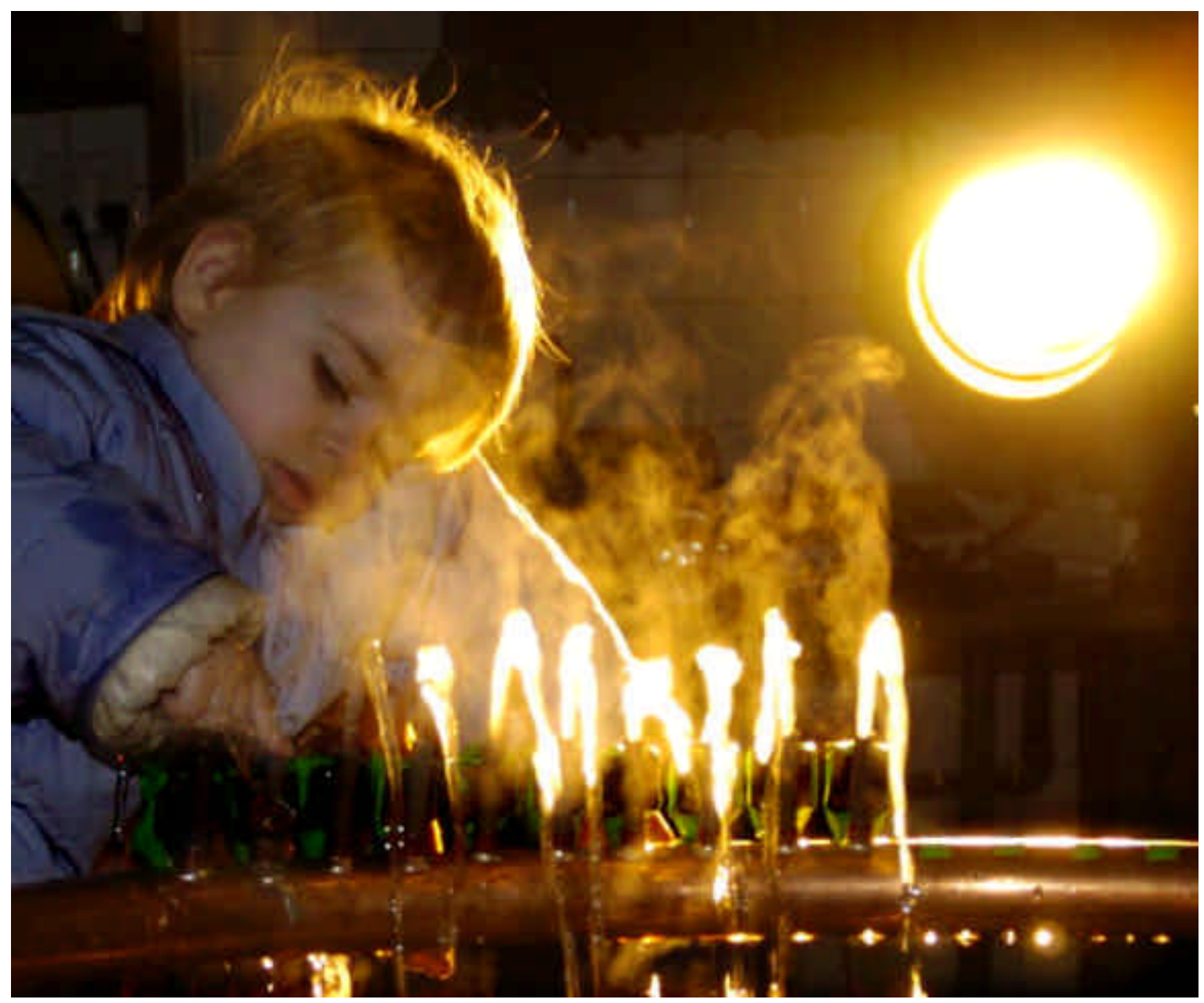

Figure 1: My 2 year old daughter wa ms up our holiday sea son by playing the popular (and easy-to-play) song, "J ingle Bells", at a FRO UC ious FUNta in performance. The FUNta in is played by blocking or partially blocking the various water jets. When I built this instrument, I included 61 jets (five octaves), but here only ten jets a re active, configured for whole-notes only (no shams or flats), in order to make it easier for a younger musician to play a simple melody.

Thus, as an avid "fountaineer" I could certainly appreciate the creative genius of artist/designer Dan Euser, when I discovered a massive always-on ( 24 hours a day, 7 or 8 months a year) splash area in the middle of the city. Although I've experienced other splash pads, the Euser creation is particularly well designed. Ground nozzles are arranged to make a series of "walls of water" that shoot out of the ground in human scale, i.e. 18 inches wide and 7 feet high (exactly ideal for an adult human). Additionally, the walls of water rise and fall, rhythmically, so that, at times, they are low enough for children to not be frightened by the roar of the water at full blast. The walls of water are sequenced to create traveling waves that move at approximately 
$20 \mathrm{~km} /$ hour which is an ideal speed at which joggers can "body surf" by staying in phase with the peak of the wave.

The creative genius of this public sculpture extends beyond its efficacy as a splash area. If it had been installed in a waterpark, it would still be a technological marvel, but what makes it particularly interesting, artistically, and culturally, as a study in urban space, is the fact that it was installed right in the middle of what is perhaps Toronto's most formal and central "Business Improvement Area". Thus it wonderfully dissolves the barrier that has traditionally existed between work and play, and between formal and informal spaces.

\section{My cup of Auld Lang Syne runneth over no more}

Labour Day is the last day of summer. That's when we should sing Auld Lang Syne to summer fun. For academics, the year begins in early September, when we go back to school, when our courses start with term 1. So Labour Day marks our year's end.

The pools, including the small wading pool in the park near where we live are all drained either Labour Day, or the day before. I watched as all the fun went down the drain, and the children gathered to the middle of the pool where the last few drops of fun remained, until even that was gone, and all that remained was the wet concrete. Even that little bit of fun soon dried up. The staff that do lifeguard duty (even the 12 inch deep wading pools need lifeguards) are students. So when the students go back to school, there's nobody to supervise the fun. And fun needs company, or at least supervision. The "splash pads" also close down, even though they don't technically require lifeguards (at least according to the manufacturers).

So where do people go for fun and frolic, or to see and be seen? The indoor pools are just not the same. There's something about the outdoor pools by the beaches that invite sunbathing. And sunbathing needs company.

So in September, the only game in town was the big fountains in Toronto's civic center, known as Dundas Square. I'd seen them before, with people saying it wasn't such a good idea to have spray nozzles scattered about the main walkway. People might get wet. You have to walk carefully through Dundas Square to avoid getting soaked, because there are six hundred spray nozzles hidden in the main walkway, underneath metal grilles, that shoot water out in various sequenced patterns, under computer programmed control.

Dundas Square was envisioned as Canada's equivalent to America's Times Square. And it's often been said that Times Square is the world's stage. It is often said that Dundas Square was intended to be Canada's stage.

The ground nozzles that reminded me so much of waterplay, at first, seemed out of place right smack in the middle of Toronto's civic and cultural epicentre. How could anyone possibly even think about being seen in a bathing suit in the middle of the city. In a Business Improvement Area, no less! 


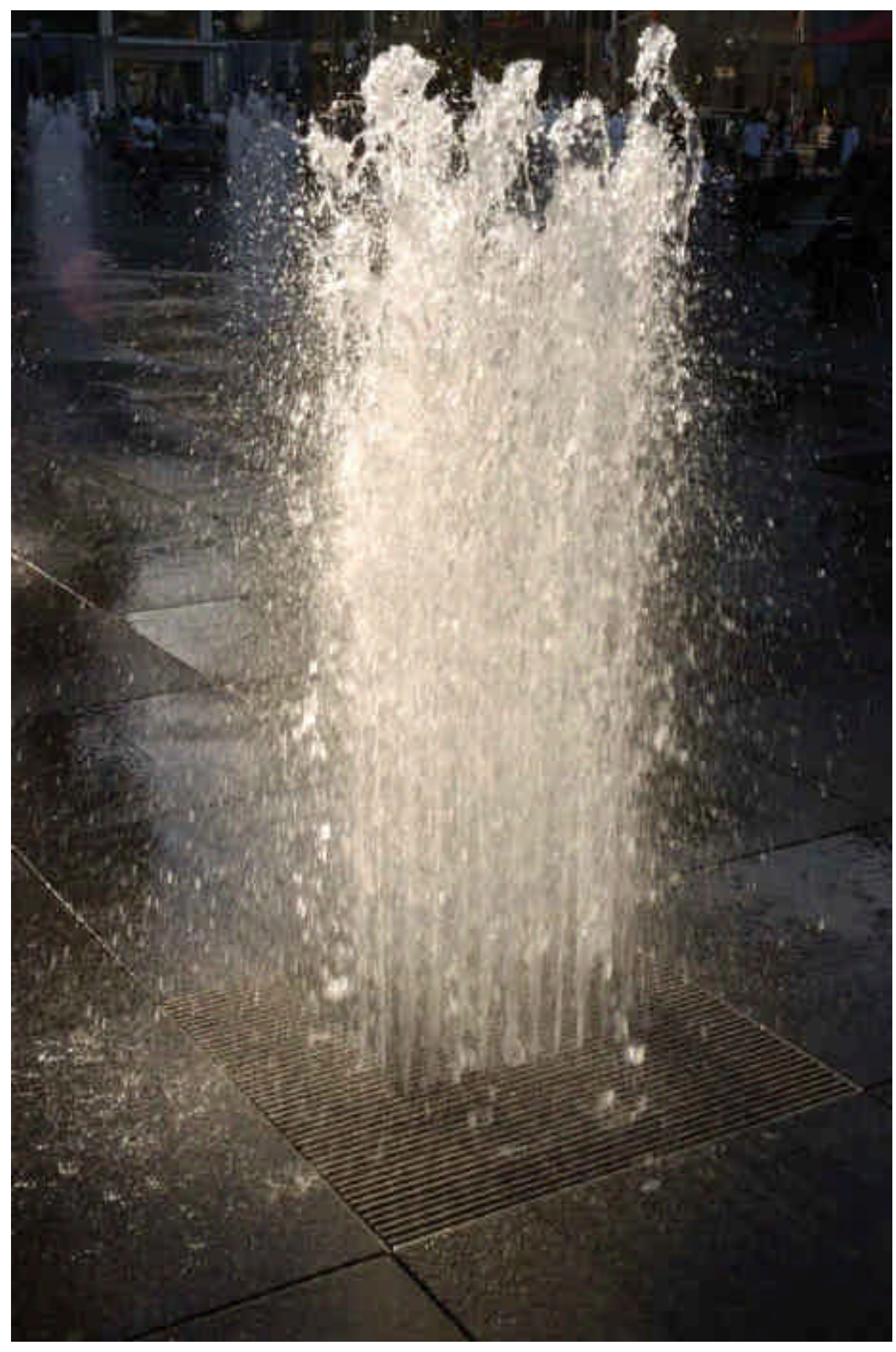

Figure 2: Ceci ce n'est pas une plage.

Wouldn't this wash away the walls, and erode the boundaries that society had erected to separate work from play? Had the planners, architects, and designer, intended the spray nozzles for waterplay? 


\section{This beach is nota mall}

At first glance, the answer might have seemed like 'no'. My 2 year old daughter and I were threatened by an aggressive Intelligarde security guard (Intelligardians of public space?). She told us: "Leave now! The police are on their way".

So I left as commanded (didn't want to spend the night in jail), but went home and did my homework. I contacted the architects (Brown + Storey Architects), the city councillor Kyle Rae, the artist Dan Euser who designed the fountains, and the facility manager, all of whom said that the fountains were designed for, and intended to be used for, waterplay. The facility manager even told me that there were changerooms to change into bathing suits. But of course nobody else there was wearing bathing suits, or playing in the fountains. Perhaps because the Intelligardes didn't think it was something that they wanted happening on their beach.

Or maybe they thought their beach was a mall, and that anyone in beach attire needed to be told: "This store is not a beach". But I thought that somebody needs to tell them, and the rest of the world that they rule, that this beach is not a store.

So I then wrote up my findings for contribution to an online encyclopaedia entry ${ }^{2}$, summarized as follows:

\section{Dundas Square}

Dundas Square is a public square in downtown Toronto, Ontario, on the southeast corner of Yonge Street and Dundas Street.

Like Times Square, in New York (which is often said to be 'the world's stage' or at least that of the USA), Dundas Square was envisioned as "Times Square North" (i.e. perhaps Canada's central defining public space).

The square is largely made with modular raised square textured 35 by 35 inch granite slabs, and features a diagonally running zinc canopy along the northern hypotenuse of he 'square', a movable plinth which serves as a stage for concerts and other performances, a row of lighted fountains set directly into the pavement, a row of trees along the southern edge, a transparent canopy over the plinth, and a new entrance to Dundas subway station below.

\section{Splash fountains}

The centerpiece of the square is the array of fountains designed by Dan Euser of Waterarchitecture. Two rows of ten fountains are spread out across the main walkway of the square, so that visitors have the opportunity to walk through or around the fountains. Unlike many other city fountains, the Dundas Square fountains were meant for waterplay, and include a sophisticated filtration system that, according to both of the architects, keeps them at or above 'pool quality' water. According to Dan Euser, the water is treated to maintain health standards for waterplay. According to facility administrator Christine MacLean, the slate that was chosen

\footnotetext{
2 http://Wikipedia.org/Dundas Square
} 
for the entire space has nonslip properties for the safety of persons running through or playing in the fountains. Each of the ten water fountains consists of a stainless steel grille with 30 ground nozzles (arranged in three rows of ten) under it.

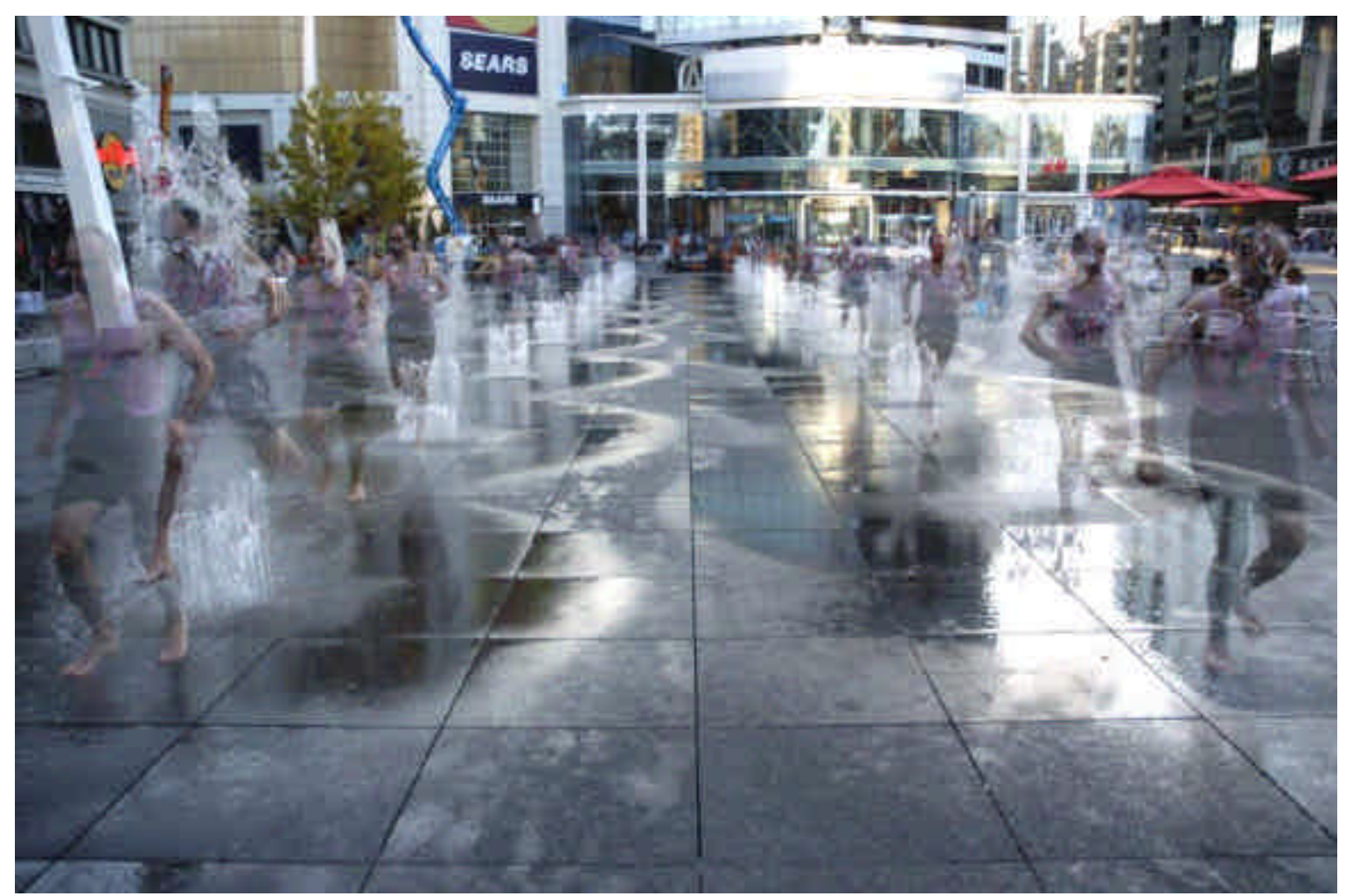

Figure 3: Multiple exposure picture showing a joggercooling off in the "urban beach" that forms the main central part of Dundas Square

The fountain amenities may be summarized as follows:

- Two rows of fountains;

- Ten fountains in each row;

- Twenty fountains in total;

- Thirty nozzles in each fountain (three rows of ten);

- 600 nozzles in total.

All 600 nozzles rise and fall in unison, in a sinusoidally time-varying fashion, to create an urban beach effect, as the 'waves' or 'surf' pounds against the hard rock surface. The water goes from approximately 1 foot high, to 8 feet high, giving rise to a peak-to-peak sinusoidal amplitude of 7 feet. At its lowest, it is suitable for toddlers to play in, and at its peak, it is intimidating to all but adults. Thus people often wait for the desired degree of splash before passing through it. Since the change is gradual, and consistent (always sinusoidal) it is predictable, and safe (i.e. a person desiring to wet only his or her feet can easily predict when to get out to avoid getting their wallet soaked, etc.). 
The entire rock surface is of a very dark (almost black) color, and absorbs sunlight quite nicely, thus creating a warm and pleasant surface to rest on, and in a nice juxtaposition with the cool refreshing water. The water runs under the dark rock slabs, and is thus heated by them, so that the fountain water is solar heated. This makes it comfortably refreshing without being too cold.

A sculptural hypotenuse canopy extends from the intersection of Yonge Street and Dundas Street, and runs at an angle closer to Dundas than Yonge. It is conveniently located to the north of the urban beach space, so that it does not cast shadows or rob the beach of natural sunlight. Washrooms/changerooms, downstairs in level P1 (part of the 250-space underground parking space below the plinth), are accessed from the Dundas Street side of the hypotenuse.

Some critics have said that when the fountains are not running (e.g. to mask out the sounds of traffic), it feels like a GO transit commuter bus station or an abandoned parking lot. Some suggest it should have monuments or other items to break up the open space, but according to Brown + Storey, the square is meant as a blank slate, a space to be filled and animated by its users. Other critics speak of the lack of people there, much of which can be attributed to one or more overzealous security guards chasing people out of the fountains or telling them not to 'loiter' (both activities having being part of the original intent of the space).

Because many people drink from the ground spray nozzles (some people even fill up their water bottles from the ground sprays), and since waterplay is one of the intended uses, the water is tested every morning, between 9am and 10am, by the health department. The water is treated with bromine, which many bathers prefer to chlorine. The quality of the experience, when all 600 nozzles are running is quite good, and crashing through the wall of water feels about equivalent to entry off a $3 \mathrm{~m}$ board into a pool (in terms of approximate equivalent splash factor). The wall of water in each fountain is nicely spaced, so as not to be so dense as to cause bruising when crashing through it, but dense enough to create a high thrill factor.

\section{On the acc countability of the Intelliguardians of Toronto's Dundas Square ${ }^{3}$}

Having been harassed by Intelligarde when I brought my family there (threatened with arrest for playing in the waterplay area), and later when I brought my students there (threatened with confiscation of my camera arising from photographing the fountains which are a popular tourist attraction), I had called Intelligarde to ask who I should address my complaint to. I was given the name Scott Suter, as the person in charge, to whom I addressed a detailed email.

In a follow up phone call I made to him, he refused to discuss the matter by phone, but promised to respond by last Thursday, and by last Friday at the very latest. He has refused to discuss this matter with me by telephone, but I have left numerous telephone messages with him, which he has failed to respond to.

\footnotetext{
${ }^{3}$ For further details, see: http://wearcam.org/dundas-square/ 
Below is a letter I sent to the company headquarters of Intelligarde International Security Company, who refer to themselves as 'THE LAW ENFORCEMENT COMPANY' (R).

\section{Letter sent to Intelligarde, "The Law Enforcement Company" (R)}

To: Scott Suter, Intelligarde

One very hot afternoon of Wed Sep 15, when the temperature was around 27.5 deg. C., my 2 year old daughter, my wife, and I came across a wonderful row of 600 ground nozzles arranged in twenty groups of 30, each group actually being (as a metal grille) one of the sidewalk slabs along a main walkway. Each was spraying upwards, all of them rising and falling gracefully in unison like the waves on a beach, and since the beautiful sprays were blocking our path along the walkway, we decided to go through them rather than around them. It was a wonderful experience that can't really be found anywhere else in the city.

Shortly afterward, a uniformed official quickly came over to us and told us that the police were on their way, and that we had better leave the area immediately. She acted very threateningly, and my daughter began to cry profusely.

I asked her what we had done wrong, and the official refused to tell us. I also asked her if she was a police officer or a parking officer, and who she worked for, and she refused to tell us. I asked her who owned the space and she refused to tell us, and said that if we did not want to spend the night in jail, we must leave immediately. By this time my daughter was very upset so we left. My daughter did not sleep well that night, which is unusual.

The official's epaulette number was 8008 .

After the incident, I talked for three or four hours with two lawyers to try and find out what laws, if any, that we might have broken. It was felt that since there was no fence or other barrier around the water sprays, or around the area known as Dundas Square, that we were not trespassing. In terms of the 'reasonable person' doctrine, it seemed that a 'reasonable person' would interpret sprayers located among sidewalk slabs of a main walkway to be intended for waterplay.

One of the lawyers, who specializes in the laws of appropriate behaviour, indicated that there was nothing inappropriate about what we did, and that there were no laws we had broken, but that a simple practical solution would be to bring the story to the attention of the media, so as to preclude a repeat. He felt that it was a matter of one security guard taking it upon herself to create a problem. He also suggested another possibility would be to contact Kyle Rae's office, since the facility is in Kyle Rae's jurisdiction. I thought this might be the best approach, rather than going to the media right away. He also suggested the 
appeal to common sense, especially in regards to an economic boost, i.e. having a fun and playful space can enhance the vibrant energy of the city, and define itself as the epicentre of Toronto, would suggest the value of tolerance for activities that do no harm to other users of the space. In fact, at the time, there were several acquaintances in the space, who had seemed delighted that we were enjoying ourselves. There was never any sense among other users of the space that we had acted inappropriately or in an anti-social way.

Therefore any attempt at an arrest would have been a 'nuisance arrest', or 'frivolous arrest', analogous to S.L.A.P.P. (nuisance lawsuits). This form of harassment is not backed by any law, but it nevertheless destroys our ability to enjoy the space. It is doubtful that any court of law would find us guilty of any crime, but the actions of the guard still make it impossible for us to enjoy ourselves, not to mention traumatizing my daughter.

It took me a while to get in touch with Kyle Rae, but meanwhile I did some research to find out who owns the space, and how it is managed.

I had trouble reaching the facilities manager, but I did write Christine MacLean who indicated that "Anyone is welcome to run through them to play and cool off", and that "The slate that was chosen has nonslip properties so the area around the fountains won't be slippery for walking through."

In a phone call, Christine also mentioned that there was even a place to change into bathing suits on level P1. This seemed like enough to indicate that we were 'reasonable' in our interpretation of waterplay being one of the possible uses of the space.

Subsequently, another security guard, much more friendly (he was quite forthcoming with his name, Peter), number 7800 told me that people regularly cool off in the spray nozzles, and that he never has any problems with that. $\mathrm{He}$ mentioned that after Canada won the hockey game, that there were a large number of people cooling off in the spray to celebrate the winning of the game. It is wonderful to see that the "child" in all of us can be free in the heart of the city. Thus there seems to be some inconsistency between 8008 and the other guards.

Just to make sure I'd 'done my homework', I also wrote to the architects Brown and Storey. They thanked me for contacting them and wrote that they were shocked that I was treated in that manner by the security. They also wrote that certainly this instance seemed "over the top", and that they were not happy that my daughter and I were treated so roughly.

They also indicated that the water that is being used in the fountains is 'pool' quality' to cover waterplay usage of the fountains. They also wished to forward my letter to the Yonge Dundas Square Management Board. 
Additionally, I contacted Tim Smith of Urban Strategies Inc., the firm that arranged the bidding process for which Brown and Story were selected. The word from Urban Strategies is that the fountains were intended to be an interactive element, and that children playing in them.

Dundas Square is a wonderful urban beach that is often deserted, through no fault of the architects, designers, or facility planners. Myself, I would have never gone back if there was another waterplay area in the city that was still open (the other splash pads are all closed at this time).

I brought this incident to the attention of my students, and one of my doctoral students told me that he has had similar troubles, and never goes there anymore.

He also called our attention to two articles about, to use his words, "overly fascist security". The articles, in Now and Eye Magazine, describe such incidents as arrests for seemingly small things like writing with chalk, etc.

Because of the outpouring of emotional support that I have experienced after the September 15th incident, from everyone involved in the design and planning of Dundas Square, I had laid the matter to rest, and had assumed that it had taken care of itself.

Recently I have been there with many of my colleagues, other faculty members, friends, etc., and we have always had a good time when 8008 was not there.

Today, I went there with some of my prospective students to take some pictures of the fountains. One of my prospective Ma.Sc. students is from India, and wears a turban. As soon as we walked over to the first fountain, to take a picture of $\mathbf{i}$, we were startled by a threatening voice demanding, "who are you with?"

At the time I was photographing the fountain with the camera on self-actuating mode (auto repeat), and I almost dropped the camera on the ground being startled by the guard (the same one, epaulette number 8008). As I turned around toward her, to see what she wanted, the camera continued to take pictures in auto-repeat mode. Thus it accidentally took one or more pictures in her general direction (see below).

She said that I had broken the law by photographing her, and she demanded that I give her the camera. I informed her that it was a web camera, and she said that it was illegal to take pictures of the fountains and put them on a web site. 
At this point, we tried to call Councillor Rae by phone, and she threatened us while we were attempting to place the call. I quickly walked away to avoid a physical assault that I would not have wanted to defend myself from.

At this time, I returned home to phone some other people for legal advice. On the way home, Councillor Rae phoned back and suggested that I talk with Ron Soskolne. After talking to both of these people and having them both confirm that there should be no problems taking pictures of the fountains, we decided to go back and see if we could complete our picture sequence. On the way back, we stopped at 52 Division to let the police know that neither Councillor Rae, nor Ron Soskolne have any problem with us taking pictures in Dundas Square. The officers suggested that I call when I reach Dundas Square and have them speak with 8008 .

However, 8008 was particularly belligerent, and was not at all interested in being accommodating to our desire to complete the picture sequence of the fountains. She talked for considerable time on our cell phone, with 52 Division PC Clark, and it seemed that no amicable solution was eminent. She seemed to have decided to keep us out of the space, no matter what arrangement I had made with Rae, Soskolne, and the officers at 52 Division.

Another security guard, epaulette number 7612 , attempted to defuse the situation, and smooth things over, but 8008 continued to act aggressively. It was not until the facilities manager Patrick Carnegie arrived on scene, that the situation cooled off.

By this time, the sun had partly set behind the tall buildings, and our remaining pictures lacked the sparkle on all 600 nozzles that we had hoped to capture.

That same day, we also talked to Mike (the 'bike guy') who sometimes does part time security work or other odd jobs in Dundas Square. He also likes the place, and himself cools off in the fountains. Additionally, as a civilian (off duty) he often picks up garbage that he finds in the space, to keep it neat and tidy. He had indicated that he's seen us using the space from time to time, and that he felt nothing we did was inappropriate or antisocial.

Tonight I had a long talk with another professor who also likes to enjoy the waterplay space, and he suggested we go there with Kyle Rae one time, and see how she reacts, or that we go there with a news crew in tow, to document her behaviour, or hire a private investigator or retired police officer to videotape her treatment of us, or at least to protect us from this crazed woman who won't leave us alone. But then I asked myself, "does my daughter need a cop to safely visit the Dundas fountain of youth?"

Some of the questions that I'd like to address are as follows: 
- Are people allowed to touch the water?

- Are people allowed to walk through the fountains?

- Are people allowed to walk barefoot in Dundas Square?

- Are men allowed to take their shirts off in Dundas Square?

- Are people allowed to take pictures of the fountains?

- Are people allowed to take pictures of security guards, especially when the guards are either committing a crime, terrorizing a child, or doing something newsworthy enough to be a picture printed on the front page of the paper?

Are any of the above illegal?

Finally, I would like to conclude by stating that I don't think 8008 is appropriate for this high profile location, during the peak months of the year (i.e. the months in which the fountains are running).

We don't feel safe or comfortable with this crazy woman hassling us, and being what we believe to be the greatest danger we face in the space.

I would like very much to talk with you, and to continue working together to see if we can work through this matter. I would like to make sure people like her are not wrecking it for everyone.

If you're unconvinced this is a problem, please let me know so I can have our next interaction with 8008 videotaped and send it to you so you can judge it for yourself, and see whether or not you are in agreement with us that 8008 represents, at the very least, a threat to our ability to enjoy the space, and at worst, a safety threat.

For my research, I wish to obtain copies of any surveillance data and reports that may pertain to me, from this afternoon, Tues. September 21, as well as from the afternoon of Wednesday, September 15th, in accordance with PIPEDA's requirements on the disclosure of surveillance data to the surveilled.

Lastly, I would like to thank the architects, designers, planners, councillor, and the other security guards, for helping me in my attempt to bring this situation to a resolve.

\section{The Response}

The Intelligarde official in charge did not respond to my email until some time later, and at that, his response was totally unapologetic, and indicates a lack of honesty. Thus it appears that Intelligarde, at least in this example, lacks both honesty (saying what they did) and integrity (doing what they said). 


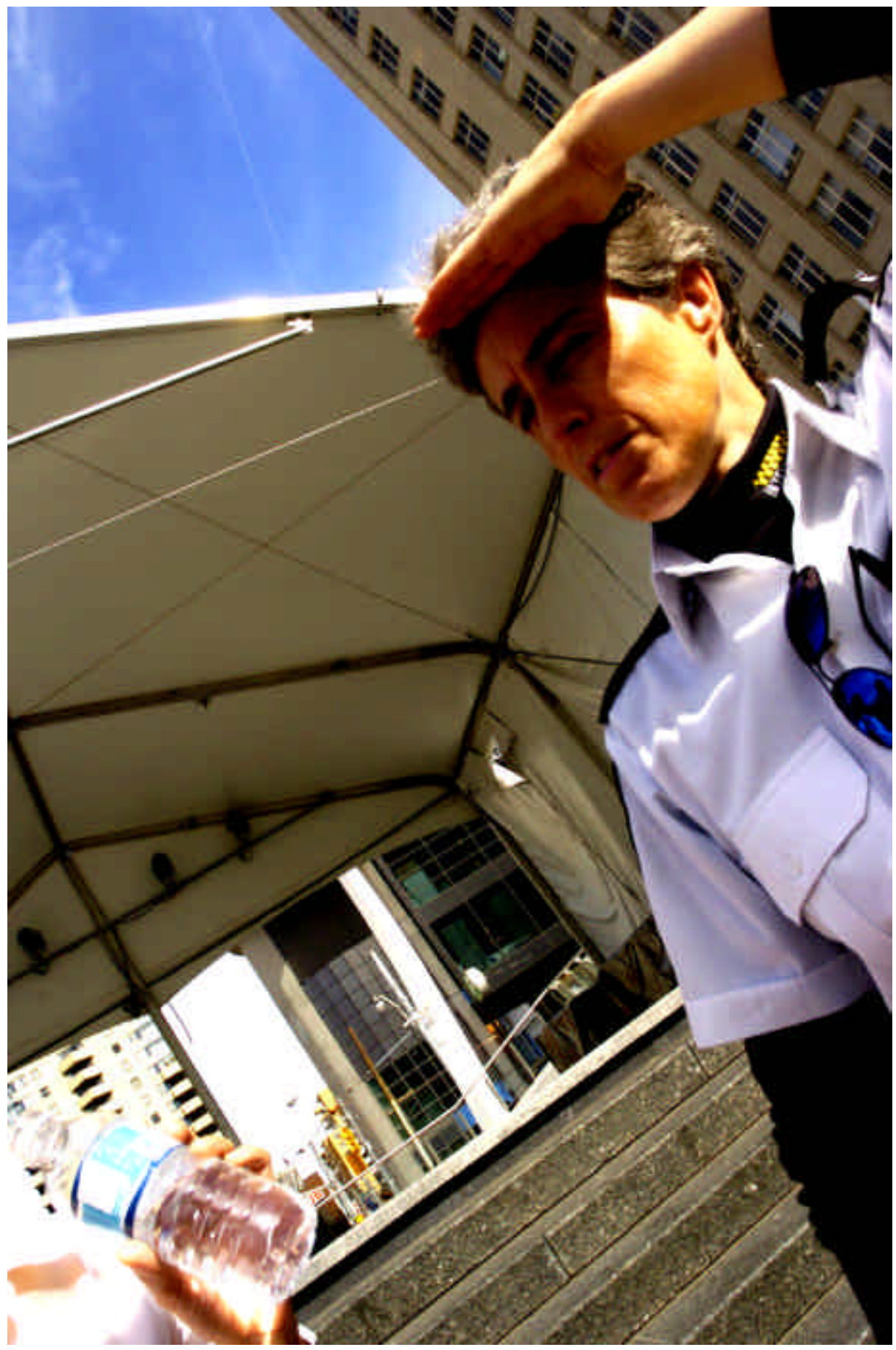

Figure 4: 8008 attempted to confisc ate camera, after standing in front of it while it was running.

This suggests a need for a way to document what happens. In particular, if citizens are to be held accountable for their actions, they should have a right to document their actions, so that they can construct a case in their defence, especially in view of possibly dishonest or corrupt security guards. One can only imagine how Intelligarde 8008 might have acted had I deliberately photographed or videotaped her. (It's unfortunate I'd taken off my EyeTap so it wouldn't get wet when I ran through the fountains). 


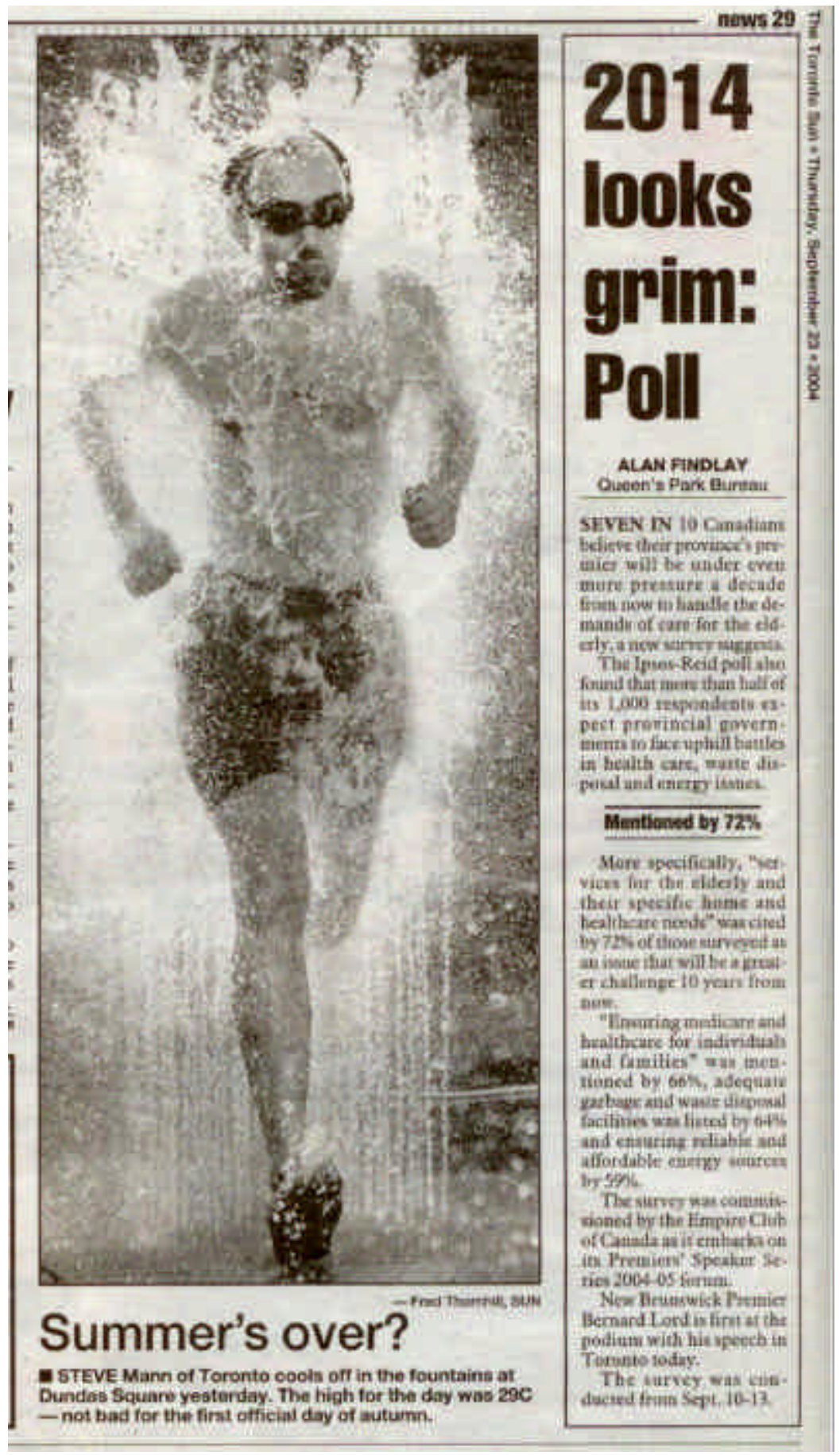

Figure 5: Summer's Over?

As it turned out, on a later visit, there was a big event there, and a Toronto Sun photographer was looking for a picture to capture the essence of the first day of autumn (above). I told him my story, and we said jokingly that we'd both meet in jail, if the laws of the land were writ large by 8008 . 


\section{Conclusions: The need for equiveillance in the face of anonauthority}

In the end, Intelligarde claimed that it had no personal data, and that the video data is with the city. This suggests a loophole in PIPEDA's requirements, namely that two different organizations (even when one is hiring the other) can separately hold data that might otherwise, when crossreferenced, fall under PIPEDA. As often, bureaucracy helps large organizations diffuse their responsibilities.

The underlying principles that come out of all of this are that:

1. we should have a right to refuse undocumented communication; and

2. authority should welcome the opportunity to maintain its monopoly.

In the first point, I conclude that we should have a right to ignore "off the record" communication. Thus if a security guard tells me that I must leave the premises immediately, I should not hear him unless I have a recording device rolling. In particular, we should have a right to use hearing aids that record everything. This would prevent me from being exposed to undocumented communication. When a guard approaches and says something, all we need to do is say "I didn't hear that, can you repeat it". We should not be expected to hear that which is not recorded. I believe therefore that the right to ignore 'off the record' communications is a necessary in inalienable right. This does not mean that we should have to record everything, but it just means that we should be able to choose to record commands that are given to us.

Additionally, by maintaining a right to record commands given to us, we ensure that our own memory of those commands is intact. In instances where the commands are never recorded, they are like the tree that falls in the forest that nobody hears. It didn't actually fall, if it wasn't recorded. If, on the other hand, the authority has a recording of the command issued to us, we should have our own right to "remember" that command.

On the second point, namely that authority should welcome accountability, this is something that would enhance the monopoly on authority. Just like I welcome the bank clerk's desire to see some identification (so that I can preserve my monopoly on the access to my own money), I would expect that authority should (or should be trained to) welcome being verified.

Similarly, when I joined the faculty at University of Toronto I needed to show an original diploma, to prove that I had completed my $\mathrm{PhD}$. I was happy to show this, and in fact I might have been angry if I were not asked to show it, because that would have indicated that it is not necessary to put in the hard work to get it.

When asking a guard for ID, we should be hearing, "thank you for asking me", along with a willingness to show it.

And likewise, we should be hearing "thank you for recording my command to you; I see you take this command very seriously and would like to remember it". When the guard complains about her picture being taken, it's a bit like a public speaker complaining that the podium is bugged (with the microphone for the PA). 
In actual fact, the guard should, like a lecturer, or presenter, be happy that we'd like to pay attention to (and remember) what they have to say.

Unless, perhaps, the guard is dishonest or corrupt.

After being traumatized, Christina was afraid of going back for a while, and cried when we came near the place where the guard was, or when she sees someone in uniform --- ironically she's now frightened of uniformed officials. But now she's starting to get back into the swim of things, at least in the evening when the space looks different (and thus isn't so likely to scare her).

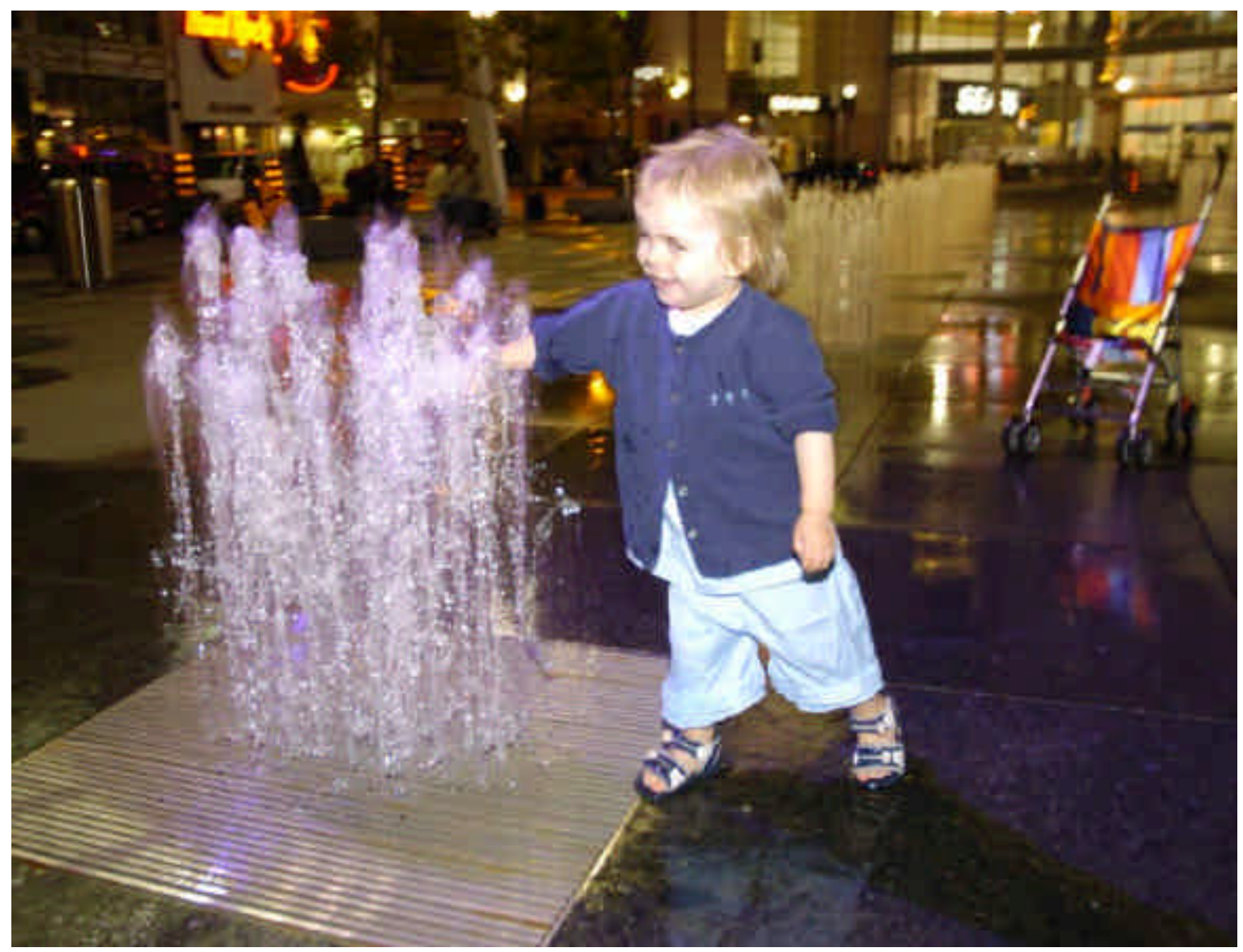

Figure 6: Christine playing at the Urbeach in the evening.

\section{People watching the people who are the people watching the people} watchers: going further with sousveilla nce

The amplified visibility of public space does not, in itself, ensure that the space remains public. In particular, I have outlined a personal narrative that speaks to the importance of accountability. The use of private security guards in civic space can be problematic. Only through integrity, honesty, and accountability can these problems be solved. In particular, when a guard demands an end to recording, that guard's words, actions, and probity should at the very least be suspect. 
Mann: People Watching People Watchers

\section{Reference}

Mann, S., J. Fung, M. Federman and G. Baccanico (2003) 'PanopDecon: deconstructing, decontaminating, and decontextualizing panopticism in the postcyborg era', Surveillance \& Society 1(3): 375-398. http://www.surveillance-and-society.org/articles1(3)/panopdecon.pdf 